\title{
Green Supply Chain of Vietnam Coffee Industry
}

\author{
Xuan Hung Nguyen \\ School of Trade and International Economics, National Economics University, 207 Giai Phong, Hai Ba Trung, \\ Ha Noi, Vietnam
}

\begin{abstract}
From a research overview of the green supply chain, the paper analyzes the current situation of Vietnam's coffee supply chain when participating in the global coffee supply chain and the green supply chain trend. On that basis, the paper implies a number of policies to green the supply chain of Vietnam's coffee industry, which is one of the key commodities of Vietnam in general and the Tay Nguyen region in particular.
\end{abstract}

Keywords: Coffee, supply chain, green supply chain, production

DOI: $10.7176 / \mathrm{EJBM} / 13-8-13$

Publication date: April $30^{\text {th }} 2021$

\section{Introduction}

Green growth is an irreversible new trend in the world today. In the context of strong globalization, there are many downsides such as exhaustion of fossil energy sources, severe environmental damage due to immediate economic benefits without paying attention to sustainable development. . Therefore, green growth is a new development method, creating a comprehensive, sustainable and harmonious development between man and nature. Many countries in the world, especially developed countries, have seen green growth as an essential driving force and direction in the activities of governments, businesses and people. Not only in the developed economies, but the trend of changing the economy from "brown" to "green" has also begun to show up and became more and more pronounced in developing economies, especially countries with good income in the group of developing countries. Despite being the second-largest coffee producer in the world, Vietnam has been still dependent on the world market without playing any role in market prices. Due to only participating in the stages of low value-added and the processing and retail distribution of major international brands, the greening of Vietnam's supply chain is passive according to the needs of importers.

In general, it is clear that greening the coffee chain is necessary if a business wants to participate in the global coffee chain. Therefore, businesses and farming households should actively cooperate with scientists to improve knowledge and adjust production methods towards green and sustainable trends. As a result, there have been many advances in farming and care techniques such as reducing the number of chemical fertilizers, pesticides, watering at the right time, and reducing the amount of watering; utilizing waste and recycling it into compost instead of chemical fertilizer ...

In spite of many improvements, there are still challenges to green Vietnam's coffee chain in future such as the cultivated area is too high compared to the plan; the groundwater level is gradually decreasing; synchronous infrastructure for green production under the model of eco-industrial zones is lacking; awareness of many households on green production is still limited; many businesses still have the thought of doing business.

\section{Overview study on green supply chain}

In recent years, the phrase "green supply chain" has been mentioned more and more. There are many terms, which have been used such as "sustainable supply chain", "sustainable green supply chain", "environmental supply chain", "ecological supply chain"...

A sustainable green supply chain can be defined as the process of using eco-friendly inputs and turning the by-products of using into the thing that can be improved or recycled in the current environment. This process enables the outputs and by-products to be reused at the end of their lifecycle so it can create a sustainable supply chain. The whole concept of a sustainable supply chain is to reduce costs and be environmentally friendly (Penfield, 2008).

Narasimhan \& Carter (1998) defines green supply chain governance as related to the use of methods that reduce materials in addition to recycling and reuse. Godfrey (1998) defines green supply chain governance as the performance of a business (DN) continuously monitoring the environmental impacts of a supply chain and improving its results. Beamon (1999) emphasizes the importance of collaborating with a company and defines green supply chain governance as the use of supply chains between a central company and a collaborative firm to support organizations like sharing ecological management know-how in companies' centers and the development of clean production techniques. Sarkis (2003) also defines green supply chain management as a combination of an environmental firm's operations and recovery logistics, which emphasizes the importance of the latter.

Classic green supply chain management strategies (Simpson \& Samson, 2008):

Risk-based strategy (RBS): This strategy includes the addition of the basic provisions of the procurement 
contract with suppliers to meet all regulatory environmental requirements which relate to ISO. Industries often choose this type of strategy primarily to invest their minimum resources in green governance and require their suppliers to comply with environmental requirements to minimize risk. Although some international environmental rules are difficult to refer to, RBS is the simplest green supply chain management strategy compared to other strategies (Chiau-Ching et al., 2011). However, in terms of competitive advantage, the benefits of this strategy are limited due to ease of implementation, lack of exclusivity, and the increasing use of other supply chains. Therefore, industries that choose this strategy cannot create a monopolistic competitive advantage so they would not gain much economic benefit from this strategy. Furthermore, these industries do not actively introduce environmental programs, cannot expect any innovation to happen. The ultimate goal of this strategy is to reduce the risk associated with passively implementing environmental programs.

Efficiency-based strategy (EBS): This is a more complex type of strategy because efficiency improves through a specific approach. Moreover, it involves responding to operations based on goals in efficiency as the "eco-efficiency" or "lean-and-green" quality standards. EBS enables industries to increase economic and environmental benefits from waste reduction and the efficient use of resources. Despite these advantages, this strategy still specializes in increasing productivity so it is not possible to completely eliminate harmful or harmful substances from the manufacturing process. Efficiency-based strategies have the advantage of cutting costs in supply chains and are well-suited to existing business optimization goals. However, it does not allow for additional high knowledge of environmental management activities such as product design, material substitution, or innovation (Simpson \& Samson, 2008). Hence, an effective strategy based on is considered a weak technique but more social than a risk-based strategy.

The primary benefit of the green supply chain is resource efficiency and environmental protection. Most logistics and transport providers implementing green supply chain models have improvements in reducing energy and waste as well as reducing packaging in distribution (Industries Canada, 2008). Businesses must comply with all legal and environmental regulations. For any international organization, the expansion and addition of new regulations can cause difficulties for the business. However, rules are in place and they have to follow if they want to stay in business. The problem is how to create a flexible and adaptive supply chain that can react quickly and with the least resources.

\section{The current status of Vietnam's coffee supply chain}

The coffee supply chain is the linkage between the production stages from the production stage to the consumer through the actors in the chain such as coffee growers, collectors, exporters, roasters, distributors and retailers to final consumers.

According to research by LMC International (2006), Oxfam (2005), Arifin, B. (2007) and some other studies, the global coffee supply chain is often linked through the following main stages:

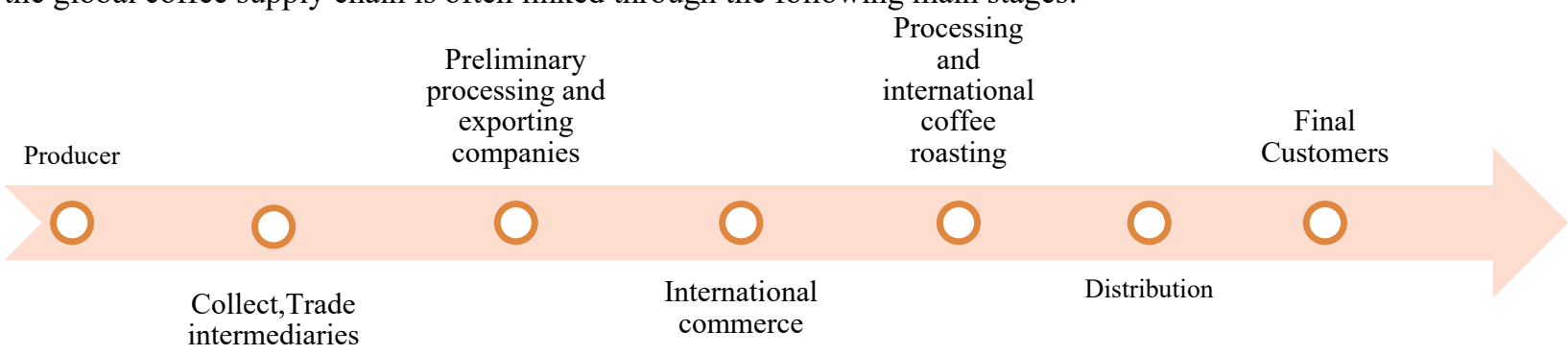

Figure 1. Global coffee supply chain

Source: Author's synthesis

\subsection{Vietnam's participation in the global coffee supply chain}

Despite Vietnam has coffee's history of more than a century and the output of the 2nd world, Vietnam does not have international coffee enterprises. Survey results in Dak Lak province show that Vietnam's participation in the global coffee supply chain is mainly from planting to preliminary processing (into green coffee) for export. 


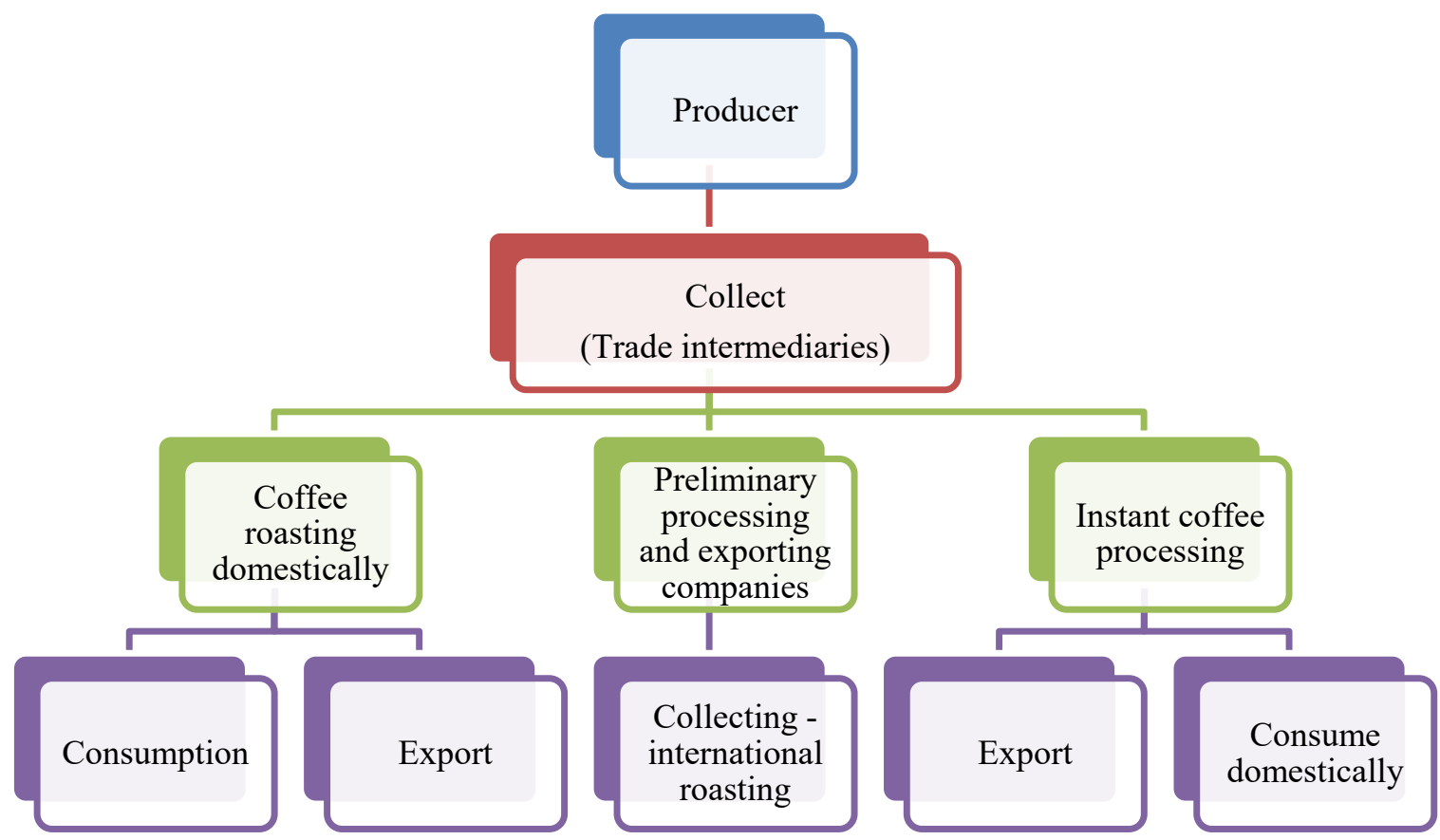

Figure 2. Vietnam's participation in the global coffee supply chain

Source: Author's survey and synthesis

In general, Vietnam has just joined the coffee chain due to its natural advantages and favorable conditions in coffee growing. There are simple and low value-added operations such as collecting and processing raw materials for export. As for the stages with high added value such as roasting, deep processing, retail distribution and product branding, Vietnam has only limited participation, mainly FDI enterprises such as Nestle, Ngon Coffee ... Some top-tier domestic enterprises of Vietnam such as Trung Nguyen, Vinacafe, .. still do not have international brands and have mainly focused on developing in the domestic market, and export accounts for a small percentage. Even without a good strategy, the domestic market will fall into well-known foreign brands such as Starbucks, Dunkin's Donuts.

Table 1. Vietnam's participation in the global coffee supply chain

\begin{tabular}{|c|c|c|c|c|}
\hline No. & Stages & Participation rate & $\begin{array}{c}\text { Participation } \\
\text { level }\end{array}$ & $\begin{array}{c}\text { Value } \\
\text { Added }\end{array}$ \\
\hline 1 & Manufacturing & Ranked No. 2 in the world & High & Medium \\
\hline 2 & $\begin{array}{l}\text { Collection and } \\
\text { preliminary } \\
\text { processing }\end{array}$ & Accounting for $20 \%$ of the world & High & Low \\
\hline 3 & Export & Ranked No. 2 in the world & High & Low \\
\hline 4 & $\begin{array}{l}\text { Roasting - deep } \\
\text { processing }\end{array}$ & $5 \%$ of the total production of Vietnam & Low & High \\
\hline 5 & $\begin{array}{l}\text { Distribution and } \\
\text { retail }\end{array}$ & Almost not involved & Low & High \\
\hline
\end{tabular}

\subsection{Key factors in the supply chain}

Source: Author's synthesis

Producers (coffee growers): In Vietnam, coffee growers are diverse, including people, cooperatives, farms, stateowned enterprises, private enterprises, etc., mainly in Tay Nguyen. Regarding coffee growers, there are many other factors such as groups that provide inputs for production (supply of materials, fertilizers, plant protection, seeds ...); capital supply groups (banks), hired labour (care, harvest); a group of state agencies such as relevant departments, associations (providing information, technical assistance, training ...).

Gathering and preliminary processing: Due to the characteristics of the coffee growing area spread throughout Tay Nguyen, the role of the collectors is important. Collecting households and agents are often organized into networks directly from communes and districts to collect both pre-processed coffee (green coffee) and freshly harvested coffee for supply and sell to the larger primary processing, roasting, processing and exporting enterprises.

Roasters, processors for export: Export processors have two main groups, including: (i) export coffee beans processing group. This is the main form in Vietnam today because most of Vietnam's exported coffee is currently raw (processing, classifying green coffee and bagging according to specifications); (ii) roasters and processors 
(powdered coffee, instant coffee and 3-in-1 coffee). Businesses and households often only roast and produce powdered coffee for domestic consumption and the volume is also negligible. There are also some deep processing enterprises (such as Nestle, Thai Hoa, Trung Nguyen) that produce instant and 3 in 1 coffee for both domestic consumption and export.

Agents outside the supply chain: Some factors outside the supply chain but have close relationships and play an important role in care technology and product direction, investment and development in the chain, which include government agencies, the cocoa coffee association, the Central Highlands Agroforestry Science and Technology Institute, Common Code for the Coffee Community (4C),...

\section{Current status of the green coffee supply chain in Vietnam}

\subsection{Coffee production process}

\section{a. Production stage (coffee growing)}

The stage of production is the stage that affects the ecological environment and the second largest greenhouse gas emissions in the coffee supply chain, second only to the consumption of coffee. Because Vietnam is only involved in the production and preliminary processing for export of green coffee, the production stage is the most decisive step towards green production for Vietnam's coffee supply chain (Figure 3).

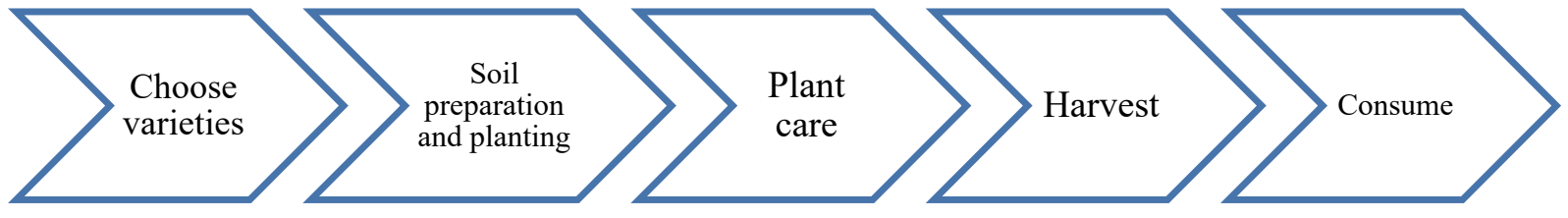

Implement green production: Reduce pesticides, chemical fertilizers. Save water, energy, recycle coffee berries waste for compost

Figure 3. Coffee production process

\section{Stage 1: Choose varieties}

This stage is mainly provided by The Western Highlands Agro-Forestry Scientific and Technical Institute (WASI) and sold to the market. The varieties sold are mainly Robusta coffee varieties due to their suitability to the natural characteristics of Tay Nguyen. The new variety has the ability to produce high yields, resist rust and resist pests and diseases, and reduce input materials. However, some households still choose their own good coffee beans for seeding.

\section{Stage 2: Soil preparation and planting}

According to the assessment of the Department of Agriculture and Rural Development of Dak Lak, and the WASI, the coffee growing techniques of Vietnamese farmers are highly appreciated compared to the world. When planting is finished, it will create a basin for watering. This technique helps plants retain moisture and fertilizer better, reducing the amount of watering and fertilizer. On the other hand, it helps prevent soil erosion and leaching.

In recent years, households also plant trees (legumes, spinach,...) to protect shade to reduce water evaporation, reduce wind impacts, increase soil fertility, balance flowering, and plant growth increases the quality of the coffee pods.

The farmers' current regular pruning also helps plants grow strong, reduce pests and grow well, pruning helps the base of the tree to retain moisture and create humus into good organic fertilizer for the soil.

In the coffee chain, the care stage is the second most influential stage (only after the coffee consumption stage) on the level of the impact on the ecological environment and the greenhouse effect because this step is related to the use of water sources, use of energy, use of chemical fertilizers and use of plant protection drugs.

Using inputs towards greening the coffee supply chain:

Watering: Irrigation water is one of the important inputs to coffee plant growth and yield. In Dak Lak province, there are more than 600 projects (lakes, dams, pumping stations) that irrigate about $25 \%$ of the coffee area. Water from rivers and streams irrigates about $26 \% \mathrm{~S}$ coffee, but mainly concentrates at the beginning of the crop (rainy season). Groundwater from dug wells and drilled wells provide water for about $50 \%$ of the coffee tree area, the density of dug wells depends on the coffee growing area near or far from rivers, streams, and about 0.5 ha has a dug well.

Annually, the amount of irrigation water used for coffee trees throughout Tay Nguyen is quite large. With an average irrigation water volume of about 1500 litres/root/year, the total amount of irrigation water needed for coffee is:

Total amount of water used $=1500$ liters $\times 1100$ base $\times 616,000$ ha $=1,016,400,000,000$ liters of water This equates to more than 1 billion cubic meters of water needed for annual watering - a remarkable amount. Currently, Tay Nguyen uses two popular irrigation methods: drip irrigation and drip irrigation, according to foreign experiences, which are only being tested as a model. 
Watering directly on the coffee root: This irrigation method is quite popular for coffee growers. This method is usually more labour intensive but requires less water than rain irrigation.

Rain irrigation: Good for the growth and development of coffee trees because rain irrigation creates a cool subregion for the garden requires less labour. However, the investment cost of equipment is higher than the original irrigation, consumes more water and higher fuel.

Drip irrigation: WASI is testing a drip irrigation model for coffee, which saves investment costs for an irrigation system at least 2/3 times compared to drip irrigation technology if imported from Israel (investment system Israel's irrigation system costs 60 million VND/ha but WASI's is only 15-20 million VND/ha). With this irrigation technology, farmers will save $20-30 \%$ of the amount of water used compared to the previous irrigation method. Moreover, coffee growers save and limit the use of chemical fertilizers as they can irrigate chemical fertilizers directly through the irrigation system, reducing the number of chemical fertilizers by about $30 \%$ due to evaporation or permeation into groundwater because the plant is not fully absorbed.

If the trial is successful and replicated to coffee growers, it will reduce irrigation water use, and reduce pressure on groundwater resources. Furthermore, with about 500 thousand hectares of coffee, a large amount of chemical fertilizer use would be reduced. The drip irrigation model will both increase economic efficiency for coffee growers and promote coffee production in a green and sustainable direction.

Among the 3 above watering methods, the rain irrigation method is the most popular way for people to use instead of pumping directly into the root as before. Although this method of irrigation uses more water, the total amount of water used per coffee crop is less because coffee growers are trained in caring techniques and they know how much watering is enough so the number of watering times and the amount of watering each time decrease. Therefore, the total amount of irrigation water is generally more economical.

\section{Use of pesticides}

The farming level of the households is quite high, has a lot of experience in coffee growing, good pruning techniques, and pest prevention, so the use of chemical drugs to protect coffee plants tends to decrease over time. However, the use of pesticides is still quite popular, every year households have to spray at least 1 time (before the coffee is ready to ripen). In addition, very few households are instructed on how to use and spray pesticides, often have to learn by themselves through books, notebooks, and reading instructions on the packaging. After using, bottles of pesticide have not been thoroughly treated; most of them are left intact and buried in the ground. The use and post-use of pesticides are still spontaneous, based on experience, mutual learning, not really safe and environmental protection (Interview with Department of Natural Resources and Environment of Dak Lak, 2014). Fertilize

A great achievement of the province in recent years is that the Center for Science and Technology Application can process yeast to incubate waste residues and coffee peels into fertilizer for crops. In the past, coffee husks were often burned or poured directly into coffee fields, now all farmers' compost them into compost mixed with probiotics (Interview with Dak Lak Department of Agriculture and Rural Development, 2014). This helps households both protect the environment while saving costs by reducing chemical fertilizers and increasing microbiological fertilizers for better soil improvement. The cost to make a ton of compost is also quite cheap compared to that of chemical fertilizers. On average, $1 \mathrm{~kg}$ of yeast costs about 50-60 thousand VND to compost 1 ton of manure with an incubation period of 1-2 months. Currently, microbiological fertilizers have replaced about 15-20\% of chemical fertilizers (Buon Me Thuot Coffee Association, 2014). Not only helps reduce chemical fertilizers, but also helps to improve soil and reduce environmental pollution caused by coffee waste.

Farmers were also instructed not to use chemical fertilizer packaging to store coffee during and after harvest. On the other hand, coffee is not dried in the ground as before and stored in a place away from humidity and fungi, not to store harvested coffee with fertilizers and pesticides.

In general, coffee production in Vietnam tends to be positive. Farmers increasingly use the input source reasonably, effectively and economically, and know-how to recycle waste into microbiological fertilizers. These changes are consistent with the greening direction of the supply chain in most countries around the world, especially in developed countries.

Households who participate in the sustainable coffee certification often follow the rules and have to record key activities such as the time of tank creation, fertilization, watering, ... and the care process is often more technical than households not participating in the certificate:

Less water for irrigation: 4C certified households, due to the technical guidance of watering at the right time, usually only water 2-3 times per year on average (depending on the amount of rainfall in the year) and each time, on average, from 400-450 litres of water/base of coffee/time. For those who do not participate, the number of watering times may be more and the amount of watering is often larger. They can water 3-5 times a year and there are times when watering can is 600 liters/root/time.

Reducing the use of chemical fertilizers and increasing microbiological fertilizers: Due to the instructions to apply fertilizers at the right time and the right amount, the amount of chemical fertilizers used is also lower than the nonparticipating households. 
Less use of chemical-based pesticides: Certified coffee has very few pesticides, farmers are trained with higher technology, can treat pests on the spot instead of watering Government (Buon Ma Thuot Coffee Association, 2014). For sustainable coffee certified households, more guidance is provided on the principle of using pesticides and not using those on the coffee spraying-prohibited list.

No herbicides used: All households having the certificate do not use herbicides during coffee cultivation. This change is due to the fact that the farmers are being trained and introduced to the long-term effects of herbicides.

Due to more scientific use of irrigation water, energy used for irrigation for certified households is also lower than for non-certified households.

In general, the use of inputs of sustainable coffee certified households tends to help greener the coffee supply chain compared to non-certified households. This is a positive sign as the number of coffee which farmers having sustainable coffee certification grow is increasing rapidly.

b. Processing stage

Preliminary processing (from fresh coffee to green coffee):

In this stage, there are two popular ways to process coffee in Vietnam: dry and wet processing. At present, dry processing is still a popular method because it is a simpler method and the investment in technology is much simpler than wet processing.

Dry processing:

Dry processing is one that has less impact on the environment and consumes much less electricity and water than wet processing. However, the selling price of green coffee is cheaper than wet processing.

In general, wet processing is more economical but uses more water, causing more environmental pollution. If there is a good environmental treatment system, wet processing will bring about higher added value.

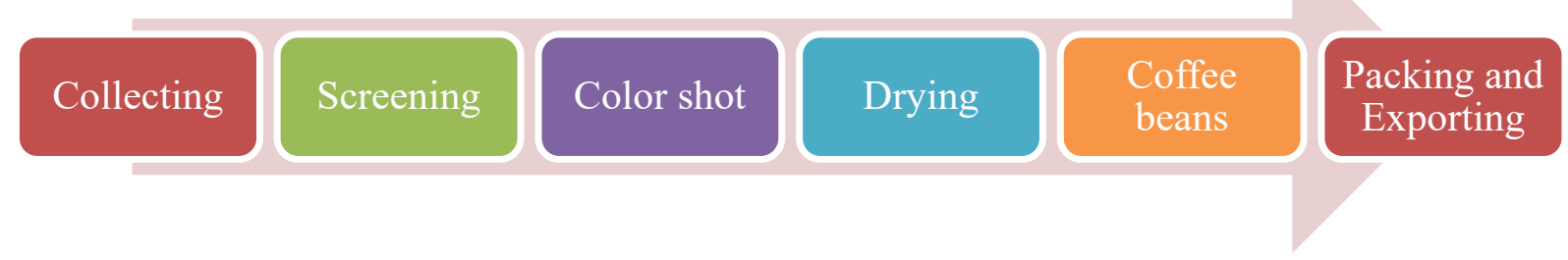

Figure 4. Dry preliminary processing process to green coffee Source: SIMEXCO DAKLAK., LTD and DAKMAN VIETNAM Limited

Wet processing:

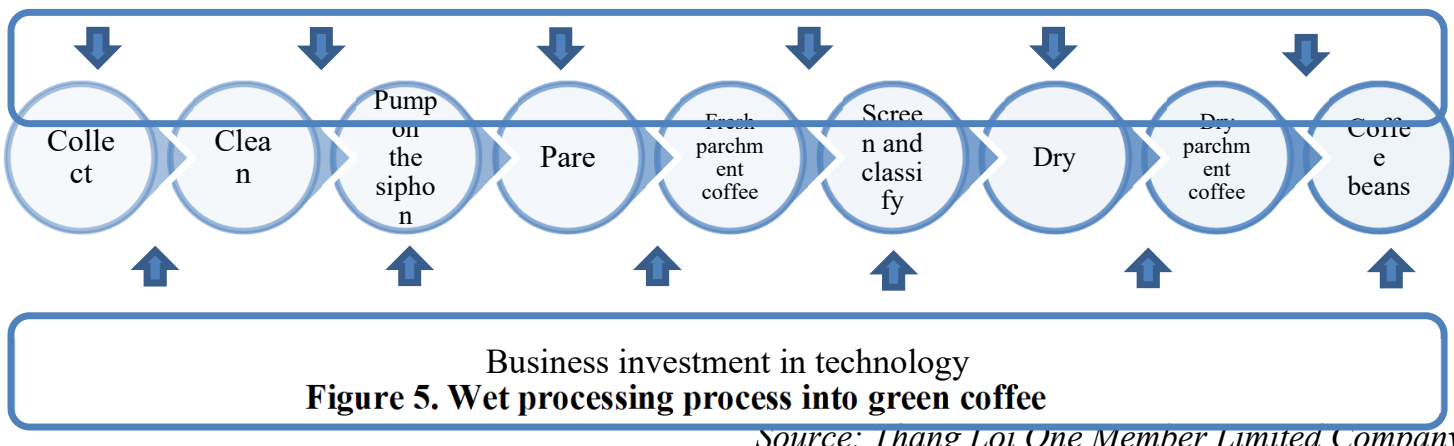
Source: Ihang Lol One Member Limited Company

At present, only very few enterprises use the wet processing method. In Dak Lak, there are one-member limited liability companies (formerly the farm) that organize the production and collection of coffee for processing wet coffee such as Phuoc An, Thang Loi, DRao, Ebok. However, only Thang Loi and Phuoc An enterprises are two of the rare companies that successfully implement the production process that meets the environmental protection criteria (Dac Lak Department of Natural Resources and Environment, 2014).

With the current processing technology of Thang Loi Company used by Vina Nha Trang, the average amount of water to process 1 ton of fresh fruit consumes $4 \mathrm{~m} 3$. This production technology reduces the amount of water used dozens of times compared to traditional wet processing ( 1 ton of fresh fruit used 40,000-70,000 litres of water in the past) (Viere et al., 2007).

Organic wastewater from fresh fruit processing requires oxygen to fully oxidize the chemicals in water (BOD). In addition, the amount of oxygen required to partially oxidize microorganism-degradable organic compounds (COD) is very high, while the $\mathrm{pH}$ is very low. Therefore, environmental treatment technology for wet processing is quite complex. Although the selling price of wet-processed green coffee is much higher than that of dry processing, this is a processing process that requires a relatively high technology investment (technology with a capacity of about 10,000 tons/year costs about 20 VND 7 billion requires an additional 7 billion for environmental 
treatment technology) so very few businesses follow this method.

Despite investing 7 billion VND in technology for wastewater treatment, Thang Loi only treats water and then discharges it into the wild, but this technology has not taken advantage of water for reuse. According to enterprises, the reason for not reusing water is still abundant and the cost is not high.

Despite investing in wastewater processing technology, it was not until 2014 that it was prepared for acceptance due to the previous failure to meet the environmental standards of Vietnam. As of January 2014, the Department of Natural Resources and Environment has not licensed any wet processing company. However, these enterprises are still operating and the province does not ban them because these businesses are still hiring consultants to research and install treatment technology.

Regarding the raw materials used for coffee drying: $50 \%$ of the fresh parchment coffee is sun-dried and $50 \%$ is dried. In the past, the company used to use coal for drying, but now it takes advantage of coffee husks for drying, both saving costs and reducing emissions and environmental pollution.

Deep processing (into powdered coffee and 3 in 1 instant coffee) Roasted and ground coffee

Coffee

beans

\section{Grind and \\ Package}

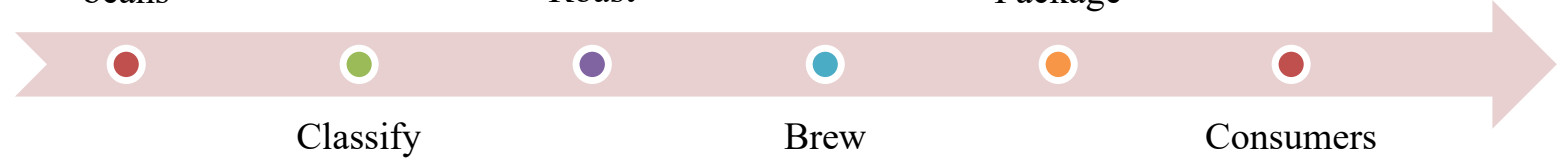

Figure 6. Coffee roasting process

Source: Quang Trinh One Member Limited Company

In the stage of roasting and deep processing (instant coffee, powdered coffee), Vietnam has also started to participate, but the proportion in the total output is still very small, only penetrating into niche markets, not yet penetrated into the large coffee consuming markets such as the EU and the US. In the retail distribution stage, Vietnam has not completely participated in the global coffee supply chain. The distribution and retail consumption of the coffee chain system are almost in the hands of big and world-famous brands.

The roasting technology of businesses and households in Vietnam mainly uses the technology of Vina Nha Trang gas roasting, so it has little impact on the environment. Moreover, this stage also uses less water and does not have much waste.

Coffee processed coffee powder, instant coffee

Processing instant coffee, 3 -in-1 coffee requires a large capital investment, modern and complex production technology, and slow capital recovery time. On the other hand, these businesses must have a professional sales system, long-term experience in market participation. Therefore, most of the businesses participating in this stage are usually brands, large enterprises with long-term business strategies. Small businesses, short-term businesses will hardly have the opportunity to participate.

According to Nielsen Vietnam, a market research company, there are currently 20 companies producing instant coffee and 3-in-1 coffee in Vietnam. Large producers in the domestic market such as Nestle, Trung Nguyen, Vinacafe, Ngon coffee, An Thai coffee,... Some roasted and ground coffee producers are also participating in the instant coffee market such as Thu Ha, Me Trang, and Phu Thai. Foreign businesses often have global brands, so the sales system, market experience, investment capital and production technology are not too big of a problem. As for domestic enterprises, most of them are state-owned enterprises on large scale, while private enterprises are businesses that have been involved in the coffee industry for a very long time and have created brand name and foothold in the domestic and international market.

In recent years, instant coffee manufacturers have also actively invested in building new factories and expanding production. For example, Nestlé built a factory worth more than 320 million US dollars in Dong Nai. Vinacafe Bien Hoa has just put into operation a 3,200-ton factory in Long Thanh, Dong Nai. In Dak Lak, Ngon Coffee Co., Ltd. from India also completed an instant coffee factory with a capacity of 10,000 tons of products/year (Hoang Phi, 2013).

\subsection{Export}

Collecting and preliminary processing enterprises mainly sell coffee beans to world roasters who have representative offices in Vietnam but less directly export to roasters in the importing country. Therefore, selling prices are often forced and completely dependent on the world market decided by the world's major traders and roasters (Interview with Dak Lak Department of Industry and Trade, 2014).

Since exporters are often representative offices of large international collectors and roasters, the office is also light and compact. Therefore, the impacts on the environment are often negligible. On the other hand, studies such as Diers et al (1999), David et al (2013) also showed that this is the stage with the least impact on the environment. 


\section{Conclusion and policy implications}

The trend of green consumption is increasingly interested in consumers around the world, especially in developed countries. Meanwhile, the demand of the market for Vietnam's coffee products depends entirely on the world's (roaster) importers to decide. In other words, the quality and specifications of coffee are driven by roasters and buyers (Ponte, 2004). Therefore, green and clean coffee production is an indispensable trend for the actors participating in Vietnam's global coffee chain. Since then, the author analyzes SWOT as follows:

\subsection{SWOT analysis of greening trends in the coffee supply chain}

\subsubsection{Strengths}

Awareness and capacity of coffee-growing businesses and households in the chain on green production has begun to improve;

Ability to adopt technology from the experience of Vietnamese farmers in coffee care;

Enterprises, farmer households with experience in the coffee industry;

The conditions for green coffee production and processing are favourable.

5.1.2 Weakness

Keeping commitments between businesses and farmers;

Short-term investment thinking (eating well), strategic vision is limited. Some enterprises have poor production capacity, business is snatched, production and purchase of coffee do not guarantee quality, environment, affecting in general. Some enterprises used to participate in certified coffee production but gave up because their financial capacity was not enough ... such as Thai Hoa Company, KrongAna (Dak Lak Department of Agriculture and Rural Development, 2014);

High green production costs: care work, processing technology, environmental treatment, membership fees for certification for sustainable coffee;

Connecting production households to green and sustainable production groups is still difficult due to the influence of the previous cooperative model;

The output does not really guarantee consumption at high prices...

5.1.3 Opportunity

The trend of green and clean consumption is increasing and this is an inevitable and encouraging trend, especially in developed countries;

The support of the state and the local government...

5.1.4 Challenges

Small area and dispersed. Most coffee acreage is owned by private individuals, households (up to 95\%) and plots are quite small (up to $85 \%$ of coffee plots are privately owned less than 1 ha) (Ipsos, 2013). Moreover, coffee growing areas are often not concentrated and dispersed everywhere. This makes it very difficult to group together to participate in certifications of sustainable coffee production;

The consumption stage is still facing difficulties. Coffee certified for clean coffee consumption in the market is mainly based on purchasing commitments of large roasters;

It is difficult to link horizontally; there is still competition between businesses.

\subsection{Some policy implications}

\subsubsection{For the government}

First, it is necessary to review the planning of the coffee growing area and take specific actions. It is necessary to determine how much area is appropriate (does not affect the amount of groundwater, forest area, ecosystems). In order to manage the planned area well, it is necessary to have scientific research to zoning off favorable and suitable areas to force households to comply with the plan. With the current mechanism, people still have the right to convert crops on their cultivated land, so it will be difficult to manage and control coffee area planning. Besides, it is necessary to combine the planning of coffee growing area with the planning of water use in the Central Highlands to ensure not over-exploitation of groundwater levels.

Second, organizing overall research and assessment of water resources for the coffee industry in Tay Nguyen. Although water is an important input to coffee production in the Central Highlands, there is currently no complete and comprehensive study on water resources as well as groundwater levels in Tay Nguyen. However, according to coffee growing households, the most obvious sign is that when wells are drilled to irrigate coffee, it is increasingly necessary to drill deeper in each area. Although water is not a serious problem for coffee production, with the current large and frequent use volume, the problem of water-saving and a comprehensive study of water and water use for coffee trees is essential.

5.2.2. For the Coffee Association

- Continue to support the program of replanting old coffee trees with new varieties that use less water for irrigation, needless chemical fertilizers and have high disease resistance;

- Raising awareness of green-clean coffee production as well as coordinating with provincial Departments of 
Agriculture to organize training on green coffee care techniques;

- Support and coordinate with businesses to find consumer markets for green-clean coffee products to encourage businesses to join the green supply chain of the Vietnamese coffee industry to become an important part of the green coffee supply chain in the world.

\section{Reference}

1. Geng, Y. \& Doberstein, B. (2008). Greening government procurement in developing countries: building capacity in China. Journal of environmental management, 88(4), pp.932-8. Available at: http:// www.ncbi.nlm.nih.gov/pubmed/17573183 [Accessed November 18, 2013].

2. Ho, L.W.P., Dickinson, N.M. \& Chan, G.Y.S. (2010). Green procurement in the Asian public sector and the Hong Kong private sector. Natural Resources Forum, 34(1), pp.24-38. Available at: http://doi.wiley. com/10.1111/j.1477-8947.2010.01274.x.

3. Qiao, Y. \& Wang, C. (2011). Issues and Challenges in Implementing China's Green Public Procurement Program. Journal of Environmental Protection, 02(08), pp.1034-1045. Available at: http://www.scirp. org/journal/PaperDownload.aspx?DOI=10.4236/jep.2011.28119 [Accessed November 18, 2013].

4. Renda, A. et al. (2012). The uptake of green public procurement in EU.

5. OECD (2003), Recommendation of the Council on Improving the Environmental Performance of Public Procurement

6. Penfield, P. (2008), Sustainability Can Be A Competitive Advantage, truy cập ngày 11-3-2014 từ trang web [http://www.mhi.org/media/ news/7056]

7. Sarkis, J. (2003), “A Strategic Decision Making Framework for Green Supply Chain Management”, Journal of Cleaner Production, Vol. 11, No. 4, pp. 397-409

8. Simpson, D.A., \& Samson, D. (2008), Developing strategies for green supply chain management,Decision Line, pp. 12-15

9. The World Bank (2011), From Growth to Green Growth: A Framework

10. UNEP FI and PRI. (2010), Universal Ownership: Why environmental externalities matter to institutional investors

11. UNEP (2011), Towards a Green Economy: Pathways to Sustainable Development and Poverty Eradication

12. Vietnam Green Purchasing Network (2014), Mua hàng xanh: nhũng nguyên tắc co bản, truy cập ngày 13-32014 từ trang web [http://www.gpn. vn/04/24/Mua-hang-xanh-nhung-nguyen-tac-co-ban.htm] 